\title{
Implementation of G. Vashchenko's Pedagogical Ideas Regarding Patriotic Education of Preschool Children in the Conditions of the Modern Preschool Institution
}

\author{
Oleksyuk Oksana Yevhenivna \\ Candidate of Pedagogical Sciences, Associate Professor, \\ Associate Professor of Pedagogy, Psychology and Inclusive Education, \\ V.O. Sukhomlynskyi Mykolaiv National University, Mykolaiv, Ukraine \\ street Nikolskaya, 24, 54030, Mykolayiv, Ukraine \\ ORCID iD https://orcid.org/0000-0002-5527-3861 \\ oleksjukoksana@ukr.net

\section{Boyko Alla Alexandrovna} \\ ORCID iD https: //orcid.org/0000-0002-5527-3861 \\ Master's Student of The Faculty of Preschool and Primary Education, \\ V.O. Sukhomlynskyi Mykolaiv National University, Mykolaiv, Ukraine \\ street Nikolskaya, 24, 54030, Mykolayiv, Ukraine \\ ORCID ID https://orcid.org/0000-0002-5527-3861 \\ e-mail: zxcvbnm22aiijj@gmail.com
}

\begin{abstract}
The article reveals the stages of pedagogical activity of educators on patriotic education of older preschool children on the basis of pedagogical ideas of G. Vashchenko. The efficiency of the offered pedagogical conditions of patriotic education of preschool children is substantiated. The forms of work with preschool children on patriotic education proposed by G. Vashchenko are described in the research.
\end{abstract}

Key words: patriotic education, preschool children, pedagogical ideas, realization, stages of pedagogical activity, pedagogical conditions

The problem of patriotic education of children and youth in Ukrainian pedagogical conception has found proper coverage. It was especially acute at the beginning of the twentieth century, during the period of national-patriotic and spiritual revival of Ukraine.

An integral component of state building in Ukraine is patriotic and civic education, which should be based on the principles of humanism, democracy, continuity and inheritance [1, p. 260]. This education should contribute to the fuller acquisition by young citizens of social experience, the inheritance of the best achievements of the people in combination with 
the acquisitions of other peoples, the establishment of a high culture of mutual relations among people of different nationalities.

The most important priority of patriotic education is the formation of a valuable attitude of the individual to the Ukrainian people, homeland, state, nation [2].

The appeal to a thorough, scientifically objective study of the national pedagogical experience testifies to the desire of modern researchers to find in the past the origins of leading ideas of today and the need to reconsider and re-evaluate educational concepts that for some reason were not considered or rejected as erroneous. G. Vashchenko's pedagogical legacy is relevant right now, when social tensions continue to grow in Ukrainian society, and conflicts that permeate all spheres of life continue.

Peculiarities of mastering knowledge about the Homeland and educating children to love it require such pedagogical means that create conditions for the interaction of emotional and intellectual factors of the process of learning and education and thus contribute to a more successful solution of tasks of formation of patriotism bases.

The strategy of national-patriotic education of children and youth (2019) identifies the following principles [2]: national orientation of education, cultural conformity, humanization of the educational process, the principle of subject-subjective interaction, integrity, acmeological principle, the principle of personal orientation, vital creative amateurism, multiculturalism, technologicalization, the principle of social correspondence, the principle of prevention.

In our opinion, patriotic education is a holistic systemic process of developing patriotic feelings aimed at the child's self-awareness as a person, a representative of his people, nation and whole humanity, which acts as an activating factor of behavioral behavior and service both to his state, his people and humanity in general.

The content of patriotic education under G. Vashchenko includes the involvement of children in the culture of the Ukrainian people, holidays, traditions, folk arts, acquaintance with family, family members, relatives, ancestors, pedigree, family traditions, acquaintance with the history of our country, conducting targeted observations of the condition of objects at different times of the year, organization of creative, productive, play activities of children.

We have developed a system of educational activities, as well as a perspective plan of work with preschoolers of the experimental group on patriotic education on pedagogical ideas 
of G. Vashchenko, which is aimed at enriching the ideas of preschool children about the Homeland.

Realization of pedagogical conditions of the formative stage of the research was carried out in accordance with the requirements of educational activities in preschool institution through the integration of all educational areas and different types of children's activities, which promotes effective learning by children about their country, native land.

At the first stage, informational, we carried out the work which consists in formation in children of preschool age system knowledge on history and culture of the Ukrainian people, the city, education of love to their Homeland, pride for it. Pedagogical work during the whole period of the research was carried out taking into account the data obtained at the ascertaining stage of the research.

At the information stage of work with preschoolers the main task was to increase children's interest in the stories about their hometown, folk crafts, national art, customs, traditions. The following forms of work were used: stories, conversations, pictures, conversations on the content of fiction, entertainment, quizzes, conversations, folk festivals, etc.

The purpose of our work at the second, practical, stage was to form children's knowledge about the Homeland, family, native city, its history and culture, holidays and traditions of the Ukrainian people. To achieve this goal, the following tasks were defined: to develop children's emotional and valuable attitude to their city, the Homeland; to form the interest of each preschooler in the present and past of the country, the ability to see the beauty around him, to cultivate respect and pride; to give preschoolers the opportunity to feel like small residents of their city, district; set a personal example to children, involving them to protect and increase the wealth of their native city.

Forms of work: frontal classes, subgroups, games, individual work with children. For this purpose, various forms of organization of children's activities are used in preschool institution, one of which is thematic classes. They are aimed at increasing children's mental activity. This is stimulated by the methods of comparison, questions, individual tasks, and the reference to children's experiences. An interesting trick was to offer to look for the answer in the illustrations, to ask parents.

Also at this stage, we organized the study of the native land with the help of excursions. 
The organization of excursions on the selected excursion routes was carried out at the following stages:

1. Preparatory stage, which provides the primary acquaintance of children with the object of the city (reading literature, viewing illustrations, children's stories, rules of conduct on the excursion - safety, care).

2. Direct acquaintance with the object of the city (story, observation, conversation with children using search questions).

3. Interaction of children with the object (the principle does not hurt).

Supporting the positive attitude of children to their native city in the process of socially oriented and creative activities of children - provided the implementation of the experience gained by children on excursions, creative productive activities, participation in activities aimed at preserving and improving the city.

Gradually, in working with children, we began to use the terms "native land" and "native city". During specially organized conversations, we clarified and extended children's knowledge about their hometown. So preschoolers became interested in studying the native land, began to express an appreciative attitude to the city in which they were born. We started our acquaintance with our native city by explaining the name and history of the city. The children were asked to consider and find out what the emblem of the city of Mykolayiv, what the symbols of the emblem of our city mean. By conducting conversations with the use of illustrations and photo albums with views of the city of Mykolayiv, we interested preschoolers, stimulated their desire to explore their native city.

The children enjoyed visiting the local history museum with great pleasure. The hostess of the museum conducts conversations, games, competitions to consolidate knowledge about the life of our ancestors. The museum presents exhibits: samples of flax and wool, embroidered napkins, woven rugs, towels, rocker, cast iron, household items. After a tour of the museum, it was decided to create its own museum within the walls of the preschool institution. A mini-museum of "Ukrainian life" was created.

A large collection of exhibits came from great-grandmothers and great-grandfathers: benches, spinning wheels, samovars, chests, jugs, and others.

After the preschoolers got acquainted with their native city, we offered children to look at the map of Ukraine and see how many different cities there are in our country. Some 
preschoolers from their own experience told about the names of the cities in which they visited with their parents. Thus, children gradually formed the idea of the boundless space of our state, that people all over Ukraine live - adults and children. That each city has its own flag and emblem, its own customs and traditions, even different is the national dress.

Along with work on acquaintance with the native city, carrying out excursions and target walks, reading of legends, art literature, acquaintance with national clothes we involved children in participation in traditional national holidays: Holiday of a harvest, Meeting of winter, St. Nicholas, Christmas, the Meeting of the Lord, Easter and others.

We also continued the acquaintance of our pupils with the historical heritage of our country, reading legends. The result was a brain-ring "My dear Mykolayiv".

At the third stage, activity-productive, the purpose of which was to involve parents in joint activities on patriotic upbringing. The main task of this stage was to acquaint parents with G. Vashchenko's pedagogical ideas on patriotic upbringing of children. Developed together with parents a strategy for patriotic upbringing of children and involvement in joint patriotic activities within the preschool institution. One of the conditions for the effective upbringing of a child is the close cooperation of educators with family members, which is the first environment where the child is formed as a person. The main components that have an educational impact on the child are the system of values and social attitudes of the family, the style of relations between family members, family traditions.

Parents became active participants in the work on patriotic upbringing of children. For parents, work was carried out on the patriotic upbringing of children (patriotic and educational orientation), joint events were held with parents: joint tours of the city, photo exhibitions on various topics, actions.

During our research we implemented various project activities in which preschoolers took a direct part, as well as held various competitions, art events, tours and exhibitions.

Summarizing the above, we can draw the following conclusions. The patriotic education of the younger generation will be more successful if from the earliest age the foundations of patriotic feelings will be laid by parents, and later brought up in a preschool institution.

For more effective work on patriotic education of preschool children it is necessary to provide the following pedagogical conditions: 
- on the basis of pedagogical ideas G.Vashchenko's patriotic education of preschoolers permeates all spheres of the child's activity, with an emphasis on the education of love for the native home, nature, culture of the Ukrainian people, the Homeland and a sense of belonging to it;

- development and implementation of a complex of measures for patriotic education of preschool children, which takes into account the gradual acquaintance of children with the Homeland;

- ensuring the cooperation of all participants in the educational process (educators, pupils and their parents), through various forms of interaction: conversations, consultations, open classes, visual information, joint projects, excursions, photo booths, entertainment, etc.

- organization of subject-development environment for patriotic education of preschool children.

The work carried out during the research and experimental work on the organization of patriotic education of preschool children on the basis of pedagogical ideas of G. Vashchenko in preschool institution gave positive results. There is a positive dynamics of the level of development of patriotic education. The obtained data prove the effectiveness of the implementation of the proposed conditions.

The results of the ascertaining and control stages of the experimental work for the experimental and control groups show that by the end of the experimental work in the experimental group the number of children with high and medium levels increased by $20 \%$ and $10 \%$ respectively and the number of children with low levels decreased by $30 \%$. The indicators obtained as a result of our work testify to the positive change in the level of patriotic education of preschool children, which allows us to judge the confirmation of our hypothesis of the study.

Thus, based on the positive dynamics that occurs as a result of work carried out in the experimental group, we can conclude that the model of implementation of pedagogical ideas of G. Vashchenko in the process of patriotic education of senior preschool children really contributes to effective patriotic education of preschoolers.

\section{References}

1. Piren M.I. Ethnopoly in Ukraine: socio-psychological analysis: a textbook. Kyiv: University "Ukraine", 2007. 408 p. 
2. Strategies of national-patriotic education of children and youth for 2020-2025 URL: https://zakon.rada.gov.ua/laws/show/932-2020-\%D0\%BF\#Text Date of application 31.10.2021

Translation of the title to the author's language

РЕАЛІЗАЦІї ПЕДАГОГІЧНИХ ІДЕЙ Г.ВАЩЕНКО ЩОДО ПАТРІОТИЧНОГО ВИХОВАННЯ ДІТЕЙ ДОШКІЛЬНОГО ВІКУ В УМОВАХ СУЧАСНОГО ЗАКЛАДУ ДОШКІЛЬНОЇ ОСВІТИ 